\title{
Od pokušenia po porozumenie - Dominik Tatarka
}

\author{
Viera Žemberová (Prešov)
}

\begin{abstract}
Abstrakt
Literárna história a kultúrna publicistika sa osobnosti a tvorbe Dominika Tatarku venujú bez ruptúr, a tak, aby sa dostali do súladu výklad spoločenských aj osobných reálií a do súvislostí dostupné interpretácie diela a okolnosti, ktoré ho utvárali, obrusovali aj popierali. Po generácii súčasníkov a rovesníkov sa posledné desatíročia dostali do dialógu post factum s Tatarkom d’alší a mladší spomedzi literárnych vedcov, poučení a s odlišne nastaveným hodnotovým zámerom. Podstatné zostáva to, že sa osobnost’ Dominika Tatarku nevytratila z poznávacích ambícií tých, čo poznajú materiál a precízne sa orientujú vo vývinovom kontexte, ale ani tých, čo nachádzajú širšie a nepovšimnutými nuansami možné dotyky jeho nazerania na seba, život, svet a umenie s inými nazeracími a estetickými konceptmi vo filozofii a umení.
\end{abstract}

\section{Klúčové slová}

Dominik Tatarka; viera; umenie; filozofia; osobnost' tvorcu; spoločenský kontext

\section{Abstract \\ From Temptation to Understanding - Dominik Tatarka}

Literary history and cultural journalism are dedicated to the personalities and works of Dominic Tatark without rupture and so that the interpretation of social and personal realities and the contexts of the available interpretations of the work and the circumstances that created, circumvented and denied it were brought into line. For generations of contemporaries and peasants, the past decades have come into the post factum dialogue with Tatark, another and younger among literary scientists, lessons and a differently set value goal. It is essential that the personality of Dominika Tatarka did not escape from the cognitive ambitions of those who know the material and precisely oriented in the context of development, but also those who find wider and unexpected nuances of possible touch of his viewing himself, life and the world and art with others advertisements and aesthetic concepts in philosophy and art.

\section{Key words}

Dominik Tatarka; faith; art; philosophy; creator personality; social context 


\section{Vyhovorit' sa, to je pre mňa priam hepening'.}

\section{Dominik Tatarka}

V slovenskej literárnej histórii sa jej poznávacia a hodnotová neprehliadnutelnost’ vo vývine literárnej a kultúrnej identity spoločenstva oživuje, potvrdzuje a predovšetkým personálne vymedzuje aj tým, že sa vo vlnách sústredeného záujmu - stredoveká literatúra, literárny romantizmus, literárny realizmus, moderna alebo L'udovít Štúr, Hviezdoslav, Vajanský, Rudolf Dilong a i. - koncentrujú výskumy prostredníctvom poučenej vykladačskej pozornosti na učebnicovo, či inak známe osobnosti z kultúrneho a literárneho dejepisu tak, aby sa rozšríili, prelínali sa, či ponúkali sa a spresnili, rozšírili, dopovedali také okolnosti, súvislosti, jednotlivosti aj pozabudnuté reálie, ktorými sa poznaním posilňuje nielen predstava o plynúcom čase a jeho obsahu v národnom a duchovnom emancipačnom spoločenstve, ale sa aj profiluje význam, hodnota, presah, závažnost̉ i záväznost̉ prítomnosti voči tomu, kto a čo bolo, ako i čo sa vôkol neho a toho dialo a čo aj ako s tým „,šetkým naložit“" v prítomnosti.

Inak to nebude s návratmi, výskumom, výkladom, či s aktualizovaním osobnosti a diela Dominika Tatarku², o ktorom sa písalo vela za jeho života i po smrti ${ }^{3}$. Dominik Tatarka oslovuje literárnych historikov, svoju účast na jeho sprítomňovaní si osvojili vydavatelia a editori jeho próz, publicistiky a „písaní“, ktoré sa rozšírili o zverejnené komorné kontakty s prozaikom ${ }^{4}$ a o samizdatové texty ${ }^{5}$.

1 TATARKA, Dominik: Sám proti noci. Bratislava: Artforum, 2017, s. 39.

2 Dominik Tatarka (14. 3. 1903 Plevník-Drienové - 10. 5. 1989 Bratislava).

3 Iniciované zhodnotením Valéra Mikulu v publikácii Démon súhlasu i nesúhlasu. Dominik Tatarka, Miroslav Válek. Dunajská Lužná: F.R.\&G., 2010; čast̉ Na úvod, s. 9. Na ilustráciu aktivity a výberovo pripomíname práce BÍLIK, René: Industrializovaná literatúra. Bratislava: Proxy, 1995; PRUŠKOVÁ, Zora: ...ked’ si tak spomeniem na šest'desiate roky. Bratislava: Proxy, 1995; Valérom Mikulom vedený projekt Čítame slovenskú literatúru I.-III. Bratislava: Ústav slovenskej literatúry SAV, 1997-1998; Ladislav Čúzy a kolektív v projekte Panoráma slovenskej literatúry I.-III. Bratislava: Slovenské pedagogické nakladatel'stvo v rokoch 2004-2006; BÁTOROVÁ, Mária: Roky úzkosti a vzopätia. Bratislava: Causa editio, 1992; JANČOVIČ, Ivan: Tvorivé začiatky Dominika Tatarku. Banská Bystrica: Univerzita Mateja Bela, 2010; MIKULA, Valér: Démoni súhlasu i nesúhlasu. Dominik Tatarka, Miroslav Válek. Dunajská Lužná: F.R.\&G., 2010; FORGÁČ, Marcel: Existencializmus a slovenská literatúra. Prešov: Prešovská univerzita, 2011; Dominik Tatarka v souvislostech světové kultury (jazyk - styl - poetika - politika). Brno: Masarykova univerzita, 2013; BÁTOROVÁ, Mária: Dominik Tatarka. Slovenský Don Quijote. Sloboda a sny. Bratislava: Veda, 2012; VYDRA, Anton - ZAJAC, Peter: Pokušenia Dominika Tatarku. Rozhovory o literatúre, spoločnosti a Slovákoch. Bratislava: W Press, 2018.

4 PODLIPNÁ, Erika: Pocta Dominikovi Tatarkovi. Praha: IPEL', 2008; ŠTOLBOVÁ, Eva: Navrávačky s Dominikom Tatarkom. Bratislava: LIC, 2000; ŠTOLBOVÁ, Eva: Sametová historie. Praha: Nakladatelství Ing. Ivan Ulrych - VE-GA-L, 2009. Denník SME z 15. 2. 2013 na s. 14 priniesol informáciu, podla ktorej v Artfore vydali k storočnici Dominika Tatarku „prvé oficiálne vydanie jeho autorského textu Navrávačky“.

5 Detailne sa osudu samizdatových textov venuje Peter Zajac v dvoch publikáciách. Do vydania prózy Dominik Tatarka: Sám proti noci. Bratislava: Artforum, 2017 pripravil Edičnú prácu, s. 118-126. Do publikácie VYDRA, Anton - ZAJAC, Peter: Pokušenia Dominika Tatarku. Rozhovory o literatúre, spoločnosti a Slovákoch sa vyjadril ku genéze textov $V$ ne čase, Písačky, Navrávačky a Listy do večnosti, o ich spojení s Jánom Mlynárikom; P. Zajac sa korektnou editorskou a mravnou normou vrátil k textom opakovane. 


\section{Vieme málo o človeku, lebo nevieme nič o smrti.}

\section{Vladimír Mináč}

V literárnych rozhovoroch pomenovaných Paradiso $^{6}$, ktoré viedla Dana Podracká a Vladimír Mináč, prišla reč aj na Dominika Tatarku. Mináčovo dôvodenie dotýkajúce sa jeho osobnosti a tvorby má jedinečnú personálnu, generačnú, dobovú, kultúrnu aj hodnotiacu patinu, ide o neprehliadnutelný vklad Mináčovej autentickej skúsenosti, ktorý zostáva pre literárnu históriu užitočný aj preto, lebo do obnovených návratov, zvlášt od devätdesiatych rokov k osobnosti a tvorbe Dominika Tatarku, si ho v literárnych súvislostiach pripomína a sprítomňuje jeden spomedzi tých, ktorí sa vracajú k jeho l’udskému a autorskému príbehu s „výhodou“ autentického dotyku s Tatarkom. Mináč naznačuje širšie súvislosti svojho návratu: „Sprítomňuje sa mi pri opätovnom čítaní Tatarkovho Démona súhlasu. "7 Lingvistické ujasňovanie si genézy slova démon, odvolania sa na iné osobnosti z európskych spoločenských a kultúrnych dejín, kde svoju rolu zohrala pozornosṫ venovaná vnútornému variovaniu pred démonickým ${ }^{8}$, nasmeruje Podracká na premýšlanie do dvojotázky, „Čo vieme o človeku?“ a „Čo vieme o Tatarkovom umieraní?" až po variácie (ú)nosnej sémantiky a možných premien démona: na démona strachu, démona dogmy a démona súhlasu s pointou účinnou voči prozaikovej autobiografii, „Démon súhlasu, Tatarkova kniha-závet, napisaná nie na konci, ale na začiatku života (roku 1956), mala zuláštny osud ${ }^{\text {“9. }}$.

Mináčovo rozvíjanie naznačených podnetov vyslovených v dvoch podstatou prepojených otázkach vyústilo do pripomenutia účinku toho, ked'sa reč dotkne smrti, do následkov navodených pragmatickostou žitých čias, teda ku konverzii v duchovnom a historickom zmysle slova ${ }^{10}$ a k pointe ustal'ujúcej Mináčovo prijímanie Tatarku v tých premenách, ktoré poznal sám z osobnej skúsenosti: „Aj po novom prečítani Démona súhlasu som si iba potvrdil to, čo som už dávno vedel, totiž, že ústredným nervom Tatarkovho ducha je viera, túžba dostat' sa do jej pevných tiesñav; na druhej strane intelektuálne formovanie týmito tiesñavami, uzavretými systémami, nech by už boli komunistické alebo katolicke."11 Napokon pre Mináča „Tatarka bol človek lyrickej viery. Vždy, ked’ sa predral, prežobral, prezajakal k svojej podstate, bol rýdzi a krásny"12.

6 MINÁČ, Vladimír - PODRACKÁ, Dana: Paradiso. Bratislava: Vydavatelstvo Spolku slovenských spisovatelov, 1998, časṫ Démon súhlasu, s. 21-26.

7 Tamže, s. 21.

8 Tamže, s. 22

9 Tamže, s. 22-23.

10 Tamže, s. 23.

11 Tamže, s. 24.

12 Tamže, s. 26. 


\section{Cena karpatského pastiera Dominika Tatarku.}

\section{Dušan Dušek}

Svoje prvé stretnutie s Dominikom Tatarkom na školou organizovanej literárnej besede si pripomenul Dušan Dušek v rozpomienke $V$ prútených kreslách ${ }^{13}$; bolo to v čase, ked' mal desat rokov a jeho čitatelská pozornost̉ sa sústredila na „chlapčenskú“ dobrodružnú literatúru, teda na čítanie lektúry prirodzene spojenej s jeho vekom a neskôr v odkaze na „knihu, ktorá sa nazýva Zločiny komunizmu na Slovensku 1948-1989?“14, ktorej udelili v roku 2001 Cenu karpatského pastiera Dominika Tatarku ${ }^{15}$. Dušekov čitatel'ský a autorský svet natrvalo spojilo s Dominikom Tatarkom a Prútenými kreslami ,jej druhé vydanie z roku 1964 [...], kniha plná jasu, prívetivej radosti a múdrosti. [...]. Nemusím nič zveličovat: kniha ma oslnila a nadchla"16. Rané spisovatel’ské skusy Dušana Dušeka sa spájajú s Tatarkom, pritom „Prútené kreslá boli pre mřa vo chvili, ked’ som začinal pisat', podobným zážitkom ako poviedky E. Hemingwaya a I. Babela, knihy F. Kafku, M. Prousta, H. Hesseho, T. Wolfa alebo W. Faulknera či iných svetových spisovatelow "17. Dušekovo empatické a ako to u neho aj býva vždy jemné, hoci z odstupu času obnovené prihováranie sa Tatarkovi, má príjemný emotívny podtón. Azda aj preto viackrát naznačuje prítomnost̉ pátosu vo svojom prístupe k jeho osobnosti a tvorbe, spomína na obdiv k spisovatelovmu naračnému remeslu, zvýrazní svoje estetické a sémantické prijímanie funkcie svetla a jasu v Tatarkovej próze, pristaví sa pri elegancii ním detailne organizovaného opisu, aby napokon zvýraznil, že ide vždy o „slovo vel'kého spisovatel'a, ked'sa vd'aka jeho majstrovstvu môžeme pri č́tani dychom a jeho literárnym jazykom dotýkat sveta okolo nás"18.

Okolnosti to tak chceli, Dušan Dušek sa dostal do blízkosti Dominika Tatarku v čase, ked' svoju situáciu v literatúre, spoločenskom a kultúrnom živote od sedemdesiatych rokov vyjadril takto, „ro už s takým spisovatelom, ktorý je tu všade zakázanyَ“19; v čase, ked' Tatarka „hovoril, že by rád napisal knižku o všetkých l'udských prejavoch, o všetkom, čo l’udia robia: od modlitby až po revolúciu. A potom ešte hovoril, že má poznámky o tom, ako teraz žije, muž na penzii, ale musel by to všetko prepisat a akosi sa mu nechce. Možno z toho neskôr boli jeho Písacky “20. Privátna rozpomienka Dušana Dušeka zaznamenaná $V$ prútených kreslách prepojila empatiu dvoch všeličím tým osobným, spoločenským, literárnym, nazeracím spomínaním na svoju minulost', aby sa naviazala na širšie súvislosti, ktoré sa nerovnakými predstavami o svojej existencii dvoch odlišných literátov v čase ich stretnutí spojili do človečiny, a tá sa im dostala nielen do vienka, ale pretrváva v ich príbehoch.

13 DUŠEK, Dušan: Vel'ká potreba lampášov. Levoča: Modrý Peter, 2018, s. 33-36.

15 Tamže, s. 37.

16 Tamže, s. 33.

17 Tamže.

18 Tamže, s. 34.

19 Tamže, s. 36.

20 Tamže. 


\section{Slovenský Don Quijote}

Spravidla to nebývajú náhody, ktoré navodia záujem literárneho vedca o konkrétnu literárnu osobnosţ alebo o problémy z vymedzeného vývinového priestoru. Zdá sa, že táto súvztažnost’ by bola vhodná pre výskum Márie Bátorovej ${ }^{21}$, ktorú spoločenské zákutia a subjekt v zložitých okolnostiach a im zodpovedajúcich rozhodnutiach inšpirujú aj v jej autorskej tvorbe. Náročnost’ rekonštrukcie a objasňovanie literárnohistorických „plôch“ v európskej aj slovenskej kultúre a literatúre ju nasmerovala ku kladeniu si nelahkých otázok, ktoré sú zacielené do historiografického a politologického kontextu. Literárnohistoricky a dobovým spoločenskovedným elektorátom sa nekonvenčne a ústretovo vyrovnat’ s autorom Dominikom Tatarkom naznačila svoj zámer Mária Bátorová v práci Dominik Tatarka. Slovenský Don Quijote. Sloboda a sny (2012). Skutočnosti, ktoré neliterárnymi zásahmi vytvorili viacero možných hodnotiacich postojov k osobnosti a tvorbe Dominika Tatarku sa metodologicky v jej koncepte sústredili na kombinovanie jestvujúcich dostredivých a odstredivých postojov voči kultúrne, politicky a občiansky činnej osobnosti v rekonštruovaných dejinných súvislostiach. Tatarkovská „téma“ má prirodzene za čas jeho prítomnosti i neprítomnosti v spoločenskom a literárnom pohybe minulého storočia svoje úskalia aj nejednoznačnosti ich objasňovania, čo najskôr do seba prijalo metonymické pomenovanie „slovenský Don Quijote“ s dôvetkom d’alšej tenzie zachytenej priblížením spojenia „sloboda a sny“. V Tatarkovom osude, v jeho individuálnosti sa, zdalo by sa, paradoxne overujú, relativizujú aj potvrdzujú reálie platné v jeho aktívnom, pritom z dnešného prístupu už iba v jeho dejinnom čase a zvyklostiach spoločnosti, v ktorej žil, ale kam nepatril z vlastnej vôle v tom úseku svojho občianskeho jestvovania a písania, zvýrazňuje, objasňuje aj rekonštruuje Mária Bátorová odkazmi na reálie z dejín spoločnosti, politiky, politológie, filozofie, krestanskej náuky a umenia. Práve ony vnútili Tatarkovmu „profilu“ v literárnohistorickom a spoločenskovednom prepojení viacero netradičných prístupov $\mathrm{k}$ ich pomenovaniu, interpretovaniu a porozumeniu. Tatarkovo ludské aj tvorivé univerzum si nachádza svoju genézu v ranom období života, v ktorom sa ukotvili a ustálili pre neho hodnoty pojmov matka, krestanstvo, príroda, spravodlivost', humanita. Napriek okolnostiam práve ony zostávajú v dostredivom bode vysvetlovania v nekonvenčných metodických sietach, v tom spočíva ústredný zámer prečo, ako a dokedy môžu spoločenské vedy preniknút, porozumiet’ Dominikovi Tatarkovi „vtedy a tam“ a Dominikovi Tatarkovi „tu a teraz“. Odkazy na filozofické iniciácie nasmerovali interpretačné prístupy k Tatarkovi na os existencializmus - krestanská filozofia, im sa Mária Bátorová venuje opakovane a možno aj opozične voči záverom, ktoré vysloví a potom relativizuje, čím potvrdzuje neustálenost’ autorovej osobnosti a súčasne potrebu vzdat sa aj literárnohistorických „klišé“ pri vyrovnávaní sa s jeho osobnou aj literárnou, nazeracou nejednoznačnostou. Tatarkov literárnohistorický portrét vytvorila Mária Bátorová ako cyklus z parciálnych mikroportrétov, ktoré sú viazané na mimoliterárne ${ }^{22}$ skutočnosti

21 BÁTOROVÁ, Mária: Dominik Tatarka. Slovenský Don Ouijote (Sloboda a sny). Bratislava: Veda, 2012.

22 BÁTOROVÁ, Mária: Op. cit., časti „Vnútri emigrácie“ ako gesto slobody (s. 24-52), Stopy „autobiografie“ vo fikcii (s. 53-80), Politické systémy 20. storočia a Obec Božia (s. 181-199), Relativistické a materialistické nazeranie na človeka (s. 208-217). Tieto časti publikácie užitočne a presvedčivo dopĺñajú početné písomné 
alebo na výklad autorovho umeleckého textu²3. Pozorné prijímanie výkladu Tatarkovho občianskeho života, kultúrnej publicistiky a aktualizovaných prozaických textov z jeho literárnej tvorby smeruje $\mathrm{k}$ výkladovým pohybom v Tatarkovom noetickom koncepte spojeným s pojmami sloboda, život, smrt', existencia, absurdita, krestanský humanizmus, samota, osamelost', l’udskost', aby na ne autorka publikácie reagovala pojmami duša, Boh, mýtus, národ, žena, čas, spoločnost', ticho, autenticita. Koncept si vyžiadal aktualizovanie Tatarkovho termínu samodefinovanie, ten je známy z neoficiálnej produkcie jeho „nahováračiek“ a „záznamov“ aj preto, aby Mária Bátorová naznačovala d’alšie netradičné a v literárnej histórii „nezabývané“ prieniky do literárneho textu a do autorského subjektu, ako naznačuje v expozícii Nohami v oblakoch, srdcom v strede. Sémantický, poznávací a hodnotový pohyb medzi Tatarkovými spojeniami proces sebazachytenia, rovina zážitku, teória siete, autenticita, vnútorná emigrácia, prirodzený svet, osobný estetický systém, či moderna verzus postmoderna vo výraze a v literárnej komunikácii, to všetko sú iniciácie obsiahnuté do problémov, ktoré čakajú na akceptáciu literárnovedným spoločenstvom, žiadajú si d’alší sémantický (prie)výskum v celku autorovho noetického a literárneho odkazu.

\section{Rekonštruovat', interpretovat' a porozumiet' spoločenskému aj kultúrnemu vývinu v ukončenom období slovenskej kultúry}

Personalizovaný démon súhlasu a nesúhlasu, ktorý Valér Mikula spája s Dominikom Tatarkom, odkazuje prostredníctvom literárneho historika na univerzum; na to, v ktorom sú dejiny národných literatúr žičlivé, poprípade ide o spoločenstvo literátov mnohotvárnych, protirečivých aj sebapopierajúcich, a tí, prirodzene, majú svoje vysvetlenia, čo sú za aj proti nemu ${ }^{24}$. K Tatarkovi ${ }^{25}$ sa Valér Mikula sústredene, rešpektujúc kategóriu času, vyjadril v publikácii Od baroka k postmoderne ${ }^{26}$ interpretačným porozumením a možnostou aplikovat termín pátos voči Tatarkovej osobnosti, k jeho premenlivému prijímaniu reality a verbálnemu „nadnášaniu“ tých reálií, ktoré sa spájali s jeho romantickým²7 prí-

i fotoarchiválie, ktoré sa menia na „hovoriace“ dokumenty doplńajúce poznanie z dejín a ako priamy nástroj na zorientovanost̉ čitatel'a.

23 Komparačný prístup zvolila Mária Bátorová pri dotykoch vybraných textov z Tatarkovej prózy a jeho náklonnost’ voči autorstvu Miguela de Unamuna, Jozefa Cígera Hronského, Alberta Camusa, Tatarkov záujem o autorské spektrum z francúzskej literatúry, záleží jej na zdôraznení osobitosti autorského subjektu v obmedzenom alebo obmedzovanom spoločenskom priestore. K posunom v jednotlivých štúdiách, z ktorých sa retazí výklad osobnosti a tvorby Dominika Tatarku v súbore Dominik Tatarka - slovenský Don Quijote - prišlo pri odvolávaní sa na možné filozofické inšpirácie k posunom medzi Platónom a Plótinom (s. 148-151) a pri žánrovom vymedzení prózy Červený Benčat', raz ako novela a po ten istý text žánrovo priradený k poviedke (s. 99-100).

24 MIKULA, Valér: Démoni súhlasu i nesúhlasu. Dominik Tatarka. Miroslav Válek. Ivanka pri Dunaji: F.R.\&G., 2010, čast’ Na úvod, s. 9.

25 Text Tatarka alebo démon pátosu vznikol v roku 1996, publikovaný bol v časopise RAK 1, 1996, č. 1, s. $24-31$.

26 MIKULA, Valér: Od baroka k postmoderne: interpretačné sondy do slovenskej literatúry. Levice: Vydavatel'stvo L.C.A., 1997.

27 Valér Mikula naznačuje prítomnost̉ tejto Tatarkovej osobnostnej dispozície, odkazuje viackrát na text Proti 
klonom k obsahom dejinnost', pretrvanie $\mathrm{v}$ zlých časoch a k povinnosti vzdelanca voči kultúrnemu povedomiu svojho spoločenstva. Pôvodnú chronologickú a interpretačnú sondu komponovanú na premenlivej prítomnosti démona súhlasu i nesúhlasu Mikula vymedzil, aby pripojil k Tatarkovmu démonovi pátosu d’alšie, dá sa naznačit, do profilu vnášané časti: Dominik Tatarka (portét), Kúpelina („Hygienická láska“ u Tatarku), Tatarkov návrat (k sebe) a v názve úsporne upravenú sondu Démon pátosu. V rekonštrukcii portrétu Dominika Tatarku sa koncentrovala Mikulova výkladová pozornost na jav a kontext takých jednotlivostí (matka, žena, úzkost', hladanie, pesimizmus, osamelost', erotika, jazyk/ reč, slovo), ktoré v živote a tvorbe prozaika zotrvali a len miniatúrne sa obrusovali vo svojich väzbách na estetické a poznávacie postoje $\mathrm{k}$ sebe, prostrediu, udalostiam a okolnostiam, v súhrne k životu ako príležitosti. Do utvárania portrétu sa po dôvodenia Mikula vrátil k časopisecky publikovaným prvotinám z tridsiatych a štyridsiatych rokov, k debutu $V$ úzkosti hladania (1942) tak, aby mohol náučne komentovat vydania d’alších textov, teda k tým, ktoré sa žánrovo priklonili k novele a románu, aby literárny a biografický portrét Tatarku uzavrel užitočným vyložením okolností okolo samizdatových textov. Pozorné prijímanie Mikulovej metódy prirad’ovania jednotlivostí z prozaickej tvorby na osi času vyústi do univerza, ním sa v Mikulovom výklade javí tvorivost̉ ako hlavný princíp Tatarkovho projektu človek ${ }^{28}$. Druhá kapitola Kúpel’̌na, „hygienická láska“ u Tatarku sa venuje interpretácii románu Farská republika (1948). Nasledujúca čast venovaná porozumeniu nuansov v živote a tvorbe prozaika, Tatarkov návrat (k sebe), sa sústredila na Prútené kreslá; tie „sú ohniskom, v ktorom sa stretávajú Tatarkove témy minulé i budúce: láska, politika, l'udská solidarita, dualizmus tela a duše, pominutel’nost'života a večnost' umenia, úzkost’ a tieser̆, ale i blaženost' a sen"29. Valér Mikula v súvislosti s reedíciou Prútených kresiel upozorňuje, a nielen literárnu históriu, na autorovu náklonnost̉ post factum upravovat', škrtat', teda "vylepšovat" svoje literárne texty, aby naznačil svoj verdikt, že výsledok tejto aktivity spôsobuje, že Tatarka „skôr ochudobnil a miestami aj oslabil [...] zrozumitelnost ${ }^{* 30}$ pôvodného vydania textu.

\section{Rozhovory o Tatarkovi, literatúre a presahu spoločnosti do umenia}

Publikácia zostavená z otázok Antona Vydru a rešpektovaných odpovedí Petra Zajaca Pokušenie Dominika Tatarku ${ }^{31}$ sa k tatarkovskej problematike priblížila prostredníctvom

démonom. Výber statí o literatúre a výtvarníctve. Bratislava: Slovenský spisovatel', 1968. Pri špecifiku Tatarkovej osobnosti sa pristaví ZAJAC, Peter: Tatarkova cesta. Slovenská literatúra 40, 1993, č. 2-3. Prevzaté z MIKULA, Valér: Démon súhlasu i nesúhlasu. Op. cit., s. 52.

28 Valér Mikula tézu tvorivosti spája s novelou Panna zázračnica, ale jej platnost̉ pokrýva Tatarkovu tvorbu ako celok, jeho koncept hodnoty a zmyslu života rešpektoval aj mimo literárneho prejavenia sa; bližšie Démon súhlasu i nesúhlasu. Op. cit., s. 17.

29 MIKULA, Valér: Démon súhlasu a nesúhlasu. Op. cit., s. 45.

30 Tamže, s. 50.

31 VYDRA, Anton - ZAJAC, Peter: Pokušenie Dominika Tatarku. Rozhovory o literatúre, spoločnosti a Slovákoch. Bratislava: W Press, 2018. 
horizontálne otváraných rozhovorov o literatúre, spoločnosti a Slovákoch. Rozhovory, predovšetkým podnety vnášané do množiny faktov, odpovedí, posúdení, názorov, hodnotení, teda nie raz aj hlušiny nevymedzených slov dotýkajúcich sa (ne)kompetentne Dominika Tatarku sú očakávaným, poučeným, dôveryhodným odborným slovom napísaným načase; ide o rozhovory od prameňa, výpovede usmerňujúce, objasňujúce, prosto užitočné rozhovory dotvárané objektívnym spoločenským a kultúrnym kontextom, o potrebné detaily, opravy, spresnenia, o profesijné podložie na účinkovanie faktov a ich neliterárnych „príbehov“. K čitatel’ovi sa dostáva publikácia spoliehajúca sa na jeho rozhladenost', preto má prostredníctvom tematických a príčinných blokov z Tatarkových želaných či vnútených „pokušení ambíciu preklenút zúžený kultúrny pôdorys okolo Dominika Tatarku, ktorý sa zabýval za posledné desatročia. Za učebnicové klišé ponúka svojské rozvinutie tých nosných téz zo sveta Dominika Tatarku, ktoré (vy)prečnievajú v čase a dejoch. Napokon prozaik ich menil na rukopisné „písačkové“ texty a realitu mimo písania sám, v osamelosti, tak to hovoril, žil, ako dokázal a mohol.

Rozhovory zahrnuté do vydania Pokušenia Dominika Tatarku si žiadajú, aby sa potrebná pozornost̉ dnes už s jasnými (pre)dosahmi do literárnej histórie a umenovedy, uchované v obsahu ním prežitých rokov, spoločenského obdobia a dobových konceptov kultúry, v ktorých Tatarka pôsobil, žil a prežival, aby sa o nich znova hovorilo v súlade so Zajacovou Edičnou poznámkou ${ }^{32}$ vloženou do vydania Tatarkovho textu Sám proti noci z roku 2017. Expozíciou Edičnej poznámky sa stala informácia, ktorá v Zajacovom precíznom faktograficky organizovanom postupe objasňuje, tým aj upravuje, odmieta mystifikácie, dohady, improvizácie naviazané na Tatarkovu tvorbu z času a tých čias, ked’ sa sám označuje za vytisnutého, zakázaného a neželaného v slovenskej kultúre a literatúre: „Autobiografický text Dominika Tatarku Sám proti noci zostavil Ján Mlynárik z autorových rukopisov, uložených v archíve Národného múzea v Prahe. Pochádzali z konvolútu 578 textov, ktoré priniesol Tatarka do Prahy, kde ich odkúpil archív cez antikvariát. Tu boli uložené 22. decembra 1976. Ich súpis dokončil Ján Mlynárik 17. januára 1977..."33. Peter Zajac rečou reálií, faktov, poznaním materiálu a súvislostí objasňuje genézu textu Sám proti noci, ale aj Tatarkov prístup k d’alším rukopisným textom v pre neho krajnej životnej situácii.

Zajacov zástoj v knihe s podtitulom je presvedčivý a dôrazný, bez emócií a naznačovaní zodpovednosti mimo Tatarku naznačuje podstatu a objasňuje osobný, spoločenský a autorský problém v súvislostiach rozložených do väzieb medzi kultúrou a spoločnostou, medzi autorom a literatúrou, do povedomia a postojov spoločnosti a Slovákov k duchovnému formovaniu neliterárnej skutočnosti.

Kultúrnu verejnosṫ na vyjdenie a užitočnosṫ Zajacových rozhovorov s Antonom Vydrom upozornil Juraj Mojžiš textom Človek pamäti kultúry s príčinným rozvinutím takto: „Tatarka sa stával človekom, ktorý v mýtickom svete žil, no zároveň ho aj vytuáral [...]“34. Rozhovory o Tatarkovi a dejinných okolnostiach spoločnosti, ňou limitovaného kultúrneho

32 ZAJAC, Peter: Edičná poznámka. In: TATARKA, Dominik: Sám proti noci. Bratislava: Artforum, 2017, s. $118-126$.

33 Tamže, s. 118.

34 MOJŽIŠ, Juraj: Človek pamäti kultúry. Denník N 4, 2018, č. 231, s. 22. Víkendové vydanie 30. 11. až 2. 12. 2018. 
a literárneho života, pojali do svojho záberu „všetko“, čím sa okolo Dominika Tatarku doteraz v jednotlivostiach dôvodilo. Peter Zajac s Antonom Vydrom to zosúladili do príčinného celku zastúpeného reáliami zo života autentického spisovatela a jedinečnej literárnej tvorby, preto sa možno v súlade s podtitulom publikácie pohybovat’ v kapitolách Sebaprepisovač, Autobiograf, Syn, Komunista, Estetik, Darca, Entuziasta, Erotik, Démonológ, Smrtelnik.

Valér Mikula zvolil metódu a postupy, ktorú mu poskytla interpretácia, prostredníctvom textu spresňoval mimoliterárne (de)formujúce súvislosti na osobnost’ tvorcu a jeho texty, Peter Zajac postupuje žánrom (sprostredkovaný literárny) rozhovor z náprotivku a stretajú sa, „Tatarka je autorom často dvoch celkom protichodných polôh“"35, ktorým dominuje jav, emócia aj súcno smrti a krásy. Blok rozhovorov zahrnutých pod názov Démonológia sa dotkne prostredníctvom textu Démon súhlasu, ten je podla Petra Zajaca našepkávač ${ }^{36}$, tematických mikrokomponentov Tatarkovho filozofovania o existencii, zla, viery, pátosu, mystiky, vášne, utrpenia, slzy, vody, výtvarného artefaktu v literárnom výraze prozaika, aby ustálil prozaika Tatarku a jeho životných démonov do vztahu príčin a ich následkov, ba aj dôsledkov takto: „Tatarka nebol len človekom literatúry, výtvarného umenia, filmu, eseje. Bol v prvom rade človekom kultúry, jej mnohonásobne sa vrstviacej a prekrývajúcej pamäti. Nebol autorom opisov a vysvetlovani, ale nezjavnej a nezjavenej imaginácie, často implicitnej,

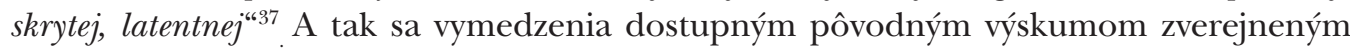
v posledných rokov objektivizovali, rozšírili a vzápätí aj ohraničili, ale výzva na poznanie, porozumenie zostáva sústredená v návrate k hodnotám, estetike, nazeraniu a jedinečnosti literárnej tvorby Dominika Tatarku.

Literárnovedné návraty k osobnosti a tvorbe, k spoločenskému kontextu a občianskemu princípu v nazeraní Dominika Tatarku na svet, život a hodnoty bytia posledné tri desat’ročia sú intenzívne a naznačujú, popri iných motiváciách, že sa s filozofujúcim umelcom, občanom a človekom Tatarkom vyrovnávajú z rozličných podnetov, s odlišným zámerom, ale vždy s ambíciou porozumiet’ a vertikalizovat’ svoje prieniky do autorových písomností. Tento zámer spája jeho rovesníkov, ale aj takých výskumníkov z kultúrneho a literárneho života, ktorí ich generačne striedajú. Zložité prežívanie autora, neustálené vyrovnávanie sa s žitou realitou sa zabývali v Tatarkovej tvorbe ako navrstvované postrehy, ktoré svojím etickým, nazeracím a emotívnym podložím prekročili svojho tvorcu, aby vykročili k potomkom.

\section{Literatúra}

BÁTOROVÁ, Mária: Dominik Tatarka. Slovenský Don Ouijote (Sloboda a sny). Bratislava: Veda, 2012. $244 \mathrm{~s}$.

DUŠEK, Dušan: Velká potreba lampášov. Levoča: Modrý Peter, 2018. 117 s.

35 VYDRA, Anton - ZAJAC, Peter: Pokušenie Dominika Tatarku. Rozhovory o literatúre, spoločnosti a Slovákoch. Bratislava: W Press, 2018, s. 138.

36 Tamže, s. 130

37 Tamže, s. 133. 
MIKULA, Valér: Od baroka k postmoderne: interpretačné sondy do slovenskej literatúry. Levice: Vydavatel'stvo L.C.A, 1997. 159 s.

MINÁČ, Vladimír - PODRACKÁ, Dana: Paradiso. Bratislava: Vydavatelsstvo Spolku slovenských spisovatelov, 1998. $362 \mathrm{~s}$.

MOJŽIŠ, Juraj: Človek pamäti kultúry. Denník N 4, 2018, č. 231, s. 22. Víkendové vydanie 30. 11. až 2. 12.2018.

VYDRA, Anton - ZAJAC, Peter: Pokušenie Dominika Tatarku. Rozhovory o literatúre, spoločnosti a Slovákoch. Bratislava: W Press, 2018. 143 s.

TATARKA, Dominik: Sám proti noci. Bratislava: Artforum, 2017. 125 s.

prof. PhDr. Viera Žemberová, CSc.

Inštitút slovakistiky a mediálnych štúdií

Filozofická fakulta, Prešovská univerzita v Prešove

Ul. 17. novembra 1, 08000 Prešov, Slovensko

viera.zemberova@ff.unipo.sk 